\title{
Evaluation of Nitrogen Bioavailability Predictors for Poultry Wastes
}

\author{
C. Wesley Wood*, Maribeth C. Duqueza and Brenda H. Wood
}

Agronomy and Soils Department, 202 Funchess Hall, Auburn University, AL 36849-5412, USA

\begin{abstract}
Long-term land application of manure, litter, and dead-bird compost generated during poultry (Gallus, gallus) production may oversupply nitrogen $(\mathrm{N})$ and result in nitrate $\left(\mathrm{NO}_{3}-\mathrm{N}\right)$ contamination of groundwater. A barrier to judicious use of poultry waste as a fertilizer is the absence of management tools for prediction of waste-derived $\mathrm{N}$ released during the plant growing season. This study was conducted to establish an $\mathrm{N}$ extraction method for poultry wastes as a predictor of soil $\mathrm{N}$ release owing to land application of poultry waste. We correlated $\mathrm{N}$ released from 87 different poultry wastes in a 60-day incubation with seven bioavailability predictors. Bioavailability predictors included autoclave-calcium chloride $\left(\mathrm{CaCl}_{2}\right)$ extraction, bicarbonate extraction, Walkley-Black (acid dichromate) digestion, acid permanganate digestion, pepsin digestion, protein extraction, and barium hydroxide extractable glucose. Results indicate that acid permanganate digestion $(r=0.77)$ has the highest potential for predicting $\mathrm{N}$ mineralized from poultry wastes followed by sodium bicarbonate extraction $(\mathrm{r}=0.51)$. However, the relationships are not strong enough to indicate that these methods would be useful in a practical, predictive sense.
\end{abstract}

Keywords: Nitrogen, poultry litter, extractants, and bioavailability predictors. Please inform me when the paper is posted.

\section{INTRODUCTION}

For decades, poultry waste has been applied to the soil both for disposal and as a nutrient source for plants. Satisfactory crop yields are obtained when poultry waste is applied at appropriate agronomic rates [1,2], but excessive rates and long-term applications can have negative agronomic and environmental implications.

An oversupply of nutrients (such as N, phosphorus (P), and others) in the soil has been found in regions heavily treated with poultry litter. In a survey of long-term littered versus non-littered tall fescue (Festuca arundinacea Schreb.) pastures in the Sand Mountain region of Alabama, levels of soil $\mathrm{NO}_{3}-\mathrm{N}>40 \mathrm{mg} \mathrm{kg}^{-1}$ were well below tall fescue root zones on littered pastures [3]. This condition has created potential for transport of waste-released $\mathrm{NO}_{3}-\mathrm{N}$ to groundwater in concentrations exceeding the maximum contaminant level of $10 \mathrm{mg} \mathrm{L}^{-1}$ set by the U.S. Environmental Protection Agency [4]. Elevated $\mathrm{NO}_{3}-\mathrm{N}$ concentrations in groundwater supplies used for human and/or livestock consumption may pose health hazards.

A management tool that would allow environmentally safe disposal of poultry wastes coupled with satisfactory crop yields would be very useful. A worthwhile tool would be a method that could predict potentially available $\mathrm{N}$ in poultry wastes prior to land application. A predictor that would help farmers decide how much litter they should apply without risking their crops or contaminating the groundwater could revolutionize poultry waste management. Such a predictor could be incorporated into programs managed by state and commercial soil testing laboratories.

*Address correspondence to this author at the Agronomy and Soils Department, 202 Funchess Hall, Auburn University, AL 36849-5412, USA;

Tel: 334-844-3997; Fax: 334-844-3945; E-mail: woodcha@auburn.edu
This study was conducted to establish an $\mathrm{N}$ extraction method from poultry wastes as a predictor of soil $\mathrm{N}$ release owing to land application of poultry waste.

\section{MATERIALS AND METHODS}

\section{Sample Collection}

Poultry waste samples consisting of broiler litter, manure from laying operations, turkey litter and dead-bird composts were collected across the southeastern U.S. (Arkansas, Mississippi, Alabama and Georgia). Poultry waste samples were collected spring in 1994, fall 1994, and spring 1995. Bedding materials encountered were wood shavings, rice hulls, sawdust, and peanut hulls. A total of 87 poultry wastes from different operations were collected throughout the experiment (Table 1). Collection of bulk samples from poultry operations consisted of sampling poultry wastes from poultry housing or waste storage facilities. Specifically, 10 random subsamples of poultry wastes from poultry housing or waste storage facilities were collected and combined to yield a 0.5 $\mathrm{m}^{3}$ composite bulk sample of each poultry waste. Each bulk sample gathered was mixed thoroughly with a cement mixer, and subsamples were collected at random from the freshly mixed bulk sample. Triplicate subsamples were ground to pass a 20 mesh sieve then maintained at $4^{\circ} \mathrm{C}$ prior to analysis.

\section{Characterization of Poultry Wastes}

Moisture content was measured for each subsample prior to chemical characterization. Chemical characterization consisted of analyses for total $\mathrm{N}$ and organic carbon (C) by dry combustion with a LECO CHN-600 analyzer (LECO Corp., St. Joseph, MI), inorganic $\mathrm{N}\left(\mathrm{NO}_{3}-\mathrm{N}\right.$ plus $\mathrm{NO}_{2}-\mathrm{N}$ and $\mathrm{NH}_{4}{ }^{-}$ $\mathrm{N}$ ) by extraction with $2 \mathrm{M} \mathrm{KCl}$ followed by measurement via standard colorimetric procedures [5] on a Lachat autoanalyzer (Lachat Quikchem Systems, Milwaukee, WI), total P, 
Table 1. Time and Number of Poultry Waste Samples Collected, Soils Incubated with Poultry Waste Samples, and Numbers of Incubations Conducted

\begin{tabular}{|c|c|c|c|}
\hline Time of Poultry Waste Collection & Number of Wastes Collected & $\begin{array}{c}\text { Soil Series Used for Incubation and } \\
\text { their Taxonomy }\end{array}$ & $\begin{array}{c}\text { Number of Soil- } \\
\text { Waste Incubations }\end{array}$ \\
\hline \hline Spring 1994 & 32 & $\begin{array}{c}\text { Norfolk - fine, loamy, siliceous, thermic } \\
\text { Typic Kandiudult } \\
\text { Hartsells - fine, loamy, siliceous, thermic } \\
\text { Typic Hapludult } \\
\text { Oktibbeha - very fine, montmorillonitic, } \\
\text { thermic, Chromic Dystrudert }\end{array}$ & $\begin{array}{c}\text { Norfolk } \\
\text { Hartsells }\end{array}$ \\
\hline Fall 1994 & 28 & $\begin{array}{c}\text { Houston - very fine, montmorillonitic, } \\
\text { thermic, Oxyaquic Hapludert }\end{array}$ & 84 \\
\hline Spring 1995 & & Norfolk & Hartsells \\
\hline Total & 27 & & 54 \\
\hline
\end{tabular}

a each incubation was done in triplicate.

potassium $(\mathrm{K})$, calcium $(\mathrm{Ca})$, magnesium $(\mathrm{Mg})$, manganese $(\mathrm{Mn})$, copper $(\mathrm{Cu})$, and zinc $(\mathrm{Zn})$ by dry ashing and extraction using dilute hydrochloric acid $(\mathrm{HCl})$ [6] then measured using Jarrel-Ash inductively coupled argon plasma spectroscopy (ICAP 9000, Thermo Jarrel Ash, Franklin, MA), and lignin, cellulose, and hemicellulose by standard chemical fiber analysis [7].

\section{Ammonium Extraction Methods}

Waste samples were extracted using the seven extraction methods described below. These methods were reported to have a potential for predicting $\mathrm{N}$ bioavailability in soil and in some organic residues. Distillable $\mathrm{N}$ (ammonium, $\left(\mathrm{NH}_{4}-\mathrm{N}\right)$ ) [5] was then determined on the different extracts (except for the waste protein) using $10 \mathrm{M}$ sodium hydroxide $(\mathrm{NaOH})$.

\section{Autoclave-CaCl${ }_{2}$ Extraction}

Waste subsamples $(1.0 \mathrm{~g})$ were placed in $50 \mathrm{~mL}$ centrifuge tubes and washed twice with $25 \mathrm{~mL}$ increments of $0.01 \mathrm{M} \mathrm{CaCl}{ }_{2}$ to remove initial mineral $\mathrm{N}$ [8]. Then $25 \mathrm{~mL}$ $0.01 \mathrm{M} \mathrm{CaCl}_{2}$ was added and the mixtures were autoclaved at $121^{\circ} \mathrm{C}$ for 16 hours. After autoclaving, the samples were centrifuged and washed twice with $25 \mathrm{~mL} 0.01 \mathrm{M} \mathrm{CaCl} \mathrm{Cl}_{2}$. The extracts and two washings were combined and volumes adjusted to $75 \mathrm{~mL}$.

\section{Sodium Bicarbonate Extraction}

Waste subsamples $(2.5 \mathrm{~g})$ were shaken with $50 \mathrm{~mL} 0.01 \mathrm{M}$ sodium bicarbonate $\left(\mathrm{NaHCO}_{3}\right)$ at high speed for 15 minutes [9]. Extracts were then filtered using Whatman no. 5 filter paper.

\section{Walkley-Black (Dichromate) Digestion}

Waste subsamples $(1.0 \mathrm{~g})$ were weighed into $500 \mathrm{~mL}$ wide-mouth flasks. Ten $\mathrm{mL} 0.5 \mathrm{M}$ potassium dichromate $\left(\mathrm{K}_{2} \mathrm{Cr}_{2} \mathrm{O}_{7}\right)$ was added and the mixtures were swirled gently while $20 \mathrm{~mL}$ concentrated sulfuric acid $\left(\mathrm{H}_{2} \mathrm{SO}_{4}\right)$ was added rapidly [10]. Flasks were swirled gently (to avoid frothing) then vigorously for 1 minute. Samples were then allowed to stand for 30 minutes to cool $[11,12]$.

\section{Acid Permanganate Digestion}

One $\mathrm{g}$ waste subsamples were weighed into $125 \mathrm{~mL}$ polyethylene bottles. Then $25 \mathrm{~mL}$ of extracting solution ( $0.05 \mathrm{M}$ potassium permanganate, $\mathrm{KMnO}_{4}$, in $\left.0.5 \mathrm{M} \mathrm{H}_{2} \mathrm{SO}_{4}\right)$ was added and mixtures were shaken for 1 hour at high speed. The mixtures were then filtered using Whatman no. 5 filter paper [13].

\section{Pepsin Digestion}

This method consisted of two parts: 1) extraction of fat by centrifugation, and 2) digestion. One $g$ waste subsamples were weighed into $15 \mathrm{~mL}$ centrifuge tubes. Ten $\mathrm{mL}$ ether was added and the mixtures were centrifuged for 15 minutes at $\geq 1750 \mathrm{rpm}$. The ether was decanted and extraction was repeated with three $5 \mathrm{~mL}$ portions of ether. Defatted samples were then air-dried in the centrifuge tubes. Defatted samples were quantitatively transferred to $250 \mathrm{~mL}$ polyethylene bottles. Then $150 \mathrm{~mL}$ freshly prepared pepsin- $\mathrm{HCl}$ solution $(2 \mathrm{~g}$ pepsin per liter of $0.075 \mathrm{~N} \mathrm{HCl}$ solution) which was prewarmed to $42-45^{\circ} \mathrm{C}$ was added to the samples. The mixtures were incubated with continuous shaking for 16 hours at $45^{\circ} \mathrm{C}$ [14] then filtered using Whatman no. 5 filter paper.

\section{Protein Extraction}

Waste subsamples $(0.05 \mathrm{~g})$ were weighed into centrifuge tubes and extracted with $25 \mathrm{~mL} \mathrm{10 \%} \mathrm{Triton} \mathrm{X-100} \mathrm{(a} \mathrm{surfac-}$ tant) at low speed for 30 minutes. The protein assay method was similar to the standard Lowry protein assay using bovine albumin serum [15] except for addition of $1.0 \mathrm{~mL} 10 \%$ sodium dodecyl sulfate (SDS) after adding the Folin reagent (1:1 Folin-phenol reagent with $\mathrm{H}_{2} \mathrm{O}$ ) [16]. Absorbances were then read at $500 \mathrm{~nm}$ on a spectrophotometer (Beckman DU 
50 Spectrophotometer, Beckman Inst., Inc., Irvine, CA). Waste protein was calculated by multiplying the protein $\mathrm{N}$ extracted by 6.25 since protein contains an average of $16 \% \mathrm{~N}$.

\section{Barium Hydroxide Extractable Glucose}

Waste subsamples $(0.5 \mathrm{~g})$ were shaken for 30 minutes with $50 \mathrm{~mL} 0.05 \mathrm{M}$ barium hydroxide $\left(\mathrm{Ba}(\mathrm{OH})_{2}\right)$ then filtered using Whatman no. 1 filter paper, discarding the first few $\mathrm{mL}$ of the filtrate. Twenty $\mathrm{mL}$ anthrone reagent $(1 \mathrm{~g}$ anthrone in cooled mixture of $475 \mathrm{~mL} \mathrm{H}_{2} \mathrm{SO}_{4}$ and $37.5 \mathrm{~mL} \mathrm{H}_{2} \mathrm{O}$ ) was added to $4 \mathrm{~mL}$ aliquots of the extracts then swirled. Mixtures were then heated on a boiling water bath for 10 minutes and absorption was measured at $625 \mathrm{~nm}$ [17] on a spectrophotometer (Beckman DU 50 Spectrophotometer, Beckman Inst., Inc., Irvine, CA).

\section{Soil Incubation}

Soil samples were collected from the Ap horizon of four soil series (Table 1). Soils were passed through a $3 \mathrm{~mm}$ screen sieve and maintained at $4^{\circ} \mathrm{C}$ prior to analysis. Moisture retention measurements were taken for each soil at -12 $\mathrm{kPa}$ using a 5-bar pressure plate extractor.

A $200 \mathrm{~g}$ subsample of each soil was weighed into separate plastic bags. Poultry wastes were added to each bag at a rate $0.8 \mathrm{~g} / 200 \mathrm{~g}$ soil which is approximately equivalent to a field application of $9 \mathrm{Mg} / \mathrm{ha}$. After thorough mixing, a $25 \mathrm{~g}$ soil-waste mixture subsample was weighed (dry weight basis) into a cup. Water was added to maintain soil and waste mixtures at a moisture content equivalent to $-12 \mathrm{kPa}$ at a bulk density of $1.3 \mathrm{~g} \mathrm{~cm}^{-3}$. The cup was then placed inside a mason jar containing $10 \mathrm{~mL}$ water to maintain humidity then sealed. The jar was incubated in the dark in a pre-set incubator at $25 \pm 1{ }^{\circ} \mathrm{C}$ for 60 days [18]. Inorganic $\mathrm{N}$, organic $\mathrm{C}$, and total $\mathrm{N}$ were measured at the start of incubations. After 60 days, inorganic $\mathrm{N}$ was measured. Inorganic $\mathrm{N}$ was extracted with $2 \mathrm{M} \mathrm{KCl}$ and measured by colorimetric procedures [18]. Organic $\mathrm{C}$ and total $\mathrm{N}$ were determined via combustion with a Leco TruSpec CN Analyzer (Leco Corp., St. Joseph, MI, USA). All analyses and incubations were done in triplicate. In addition to soil-waste incubations, soils without waste addition (controls) were incubated in the manner described above. Potential $\mathrm{N}$ mineralization was determined by subtracting initial inorganic $\mathrm{N}$ from inorganic $\mathrm{N}$ measured at the end of the 60-day incubation. Nitrogen mineralized from poultry wastes was calculated as the difference between potential $\mathrm{N}$ mineralization of waste amended and control soils.

\section{Statistical Analysis}

Nitrogen mineralized by soil incubation was correlated and linearly regressed against the various waste $\mathrm{N}$ extraction methods using the SAS package [19].

\section{RESULTS AND DISCUSSION}

\section{Waste Characteristics}

Moisture measurements were comparable to values previously reported [20-22].

Total $\mathrm{N}$ content was typical of poultry wastes [20-22]. Inorganic $\mathrm{N}$ was primarily $\mathrm{NH}_{4}-\mathrm{N}$ with lesser amounts of
$\mathrm{NO}_{3}-\mathrm{N}$. Carbon:N ratios $(\mathrm{C}: \mathrm{N})$ were in a range that indicated that $\mathrm{N}$ in the poultry wastes was mineralizable. The wastes had micronutrient contents in agreement with previously reported values [20-22]. The standard chemical fiber analysis values for lignin were low, while more easily decomposable cellulose and hemicellulose were double that of lignin (Table 2).

Selected poultry waste characteristics were correlated with $\mathrm{N}$ mineralized from incubations (Table 3). Organic $\mathrm{C}$, $\mathrm{NO}_{3}-\mathrm{N}, \mathrm{NH}_{4}-\mathrm{N}$, lignin, and hemicellulose gave significant correlations while total $\mathrm{N}, \mathrm{C}: \mathrm{N}$ ratio, and cellulose gave no significant correlations. Although the significant correlations obtained were weak and of little value in prediction of $\mathrm{N}$ mineralization from poultry wastes.

\section{Bioavailability Predictors}

Correlation analysis of the chemical (bioavailability) predictors with incubation resulted in significant correlations, but correlation values were low. The $\mathrm{r}^{2}$ values ranged from 0.07 to 0.61 (Table 4). Acid permanganate digestion gave the highest coefficient of determination, followed by sodium bicarbonate extraction. Other predictors had very low coefficients of determination (Table 4). The barium hydroxide extractable glucose method was discontinued due to color interferences by organic compounds in wastes. Decolorizing agents such as activated charcoal and hydrogen peroxide were tried to no avail.

Nitrogen released by the bioavailability predictors was much greater than that mineralized during incubation (Table 4). This disparity may be due to inorganic $\mathrm{N}$ losses during incubation that were not realized by the chemical tests. Possible $\mathrm{N}$ loss pathways included volatilization, denitrification, or immobilization. These $\mathrm{N}$ losses typically occur when high ammonia $\left(\mathrm{NH}_{4}-\mathrm{N}\right)$ content wastes are applied to the soil and such losses vary with waste and soil types [23]. A decrease in inorganic $\mathrm{N}$ from soil incubated with poultry waste may attribute the loss to $\mathrm{NH}_{3}-\mathrm{N}$ volatilization [24]. Nitrogen loss is apparent in this study since $\mathrm{C}: \mathrm{N}$ ratios of the wastes (Table 2) indicate that $\mathrm{N}$ was highly available, but incubation results showed that low amounts of $\mathrm{N}$ were mineralized with immobilization occurring in some cases (Table 4). Bedding materials, such as pine shavings, peanut hulls, sawdust, and rice hulls have been suggested as immobilizing agents [25].

Another factor influencing the results of this study is the apparent "harshness" of the chemical methods chosen for evaluation of bioavailability predictors. All predictors tested extracted amounts of $\mathrm{N}$ that were one to two orders of magnitude greater than that obtained during incubation (Table 4). The results suggest that a less harsh chemical extractant may need to be tried.

\section{Autoclave-CaCl${ }_{2}$ Extraction}

Autoclaving at elevated temperature and pressure reportedly increases the amount of organic $\mathrm{N}$ dissolved and hydrolyzed, such as amides and amino sugars [26], thereby increasing the amount of $\mathrm{N}$ released during the process. Results from this study, however, showed that $\mathrm{N}$ released was relatively small after 16 hours of autoclaving poultry litter in $0.01 \mathrm{M} \mathrm{CaCl}{ }_{2}$ at $121^{\circ} \mathrm{C}$ compared to the other predictors and correlation with $\mathrm{N}$ released during incubation was low ( $\mathrm{Ta}$ ble 4). Nitrogen losses may have occurred after a long sub- 
Table 2. Selected Characteristics of Poultry Wastes Used in the Study ${ }^{\mathrm{a}}$

\begin{tabular}{|c|c|c|c|c|}
\hline Component & Minimum & Maximum & Mean & Std. Error \\
\hline $\mathrm{C} / \mathrm{N}$ & 5.0 & 12.9 & 8.7 & 0.1 \\
\hline \multicolumn{5}{|c|}{ 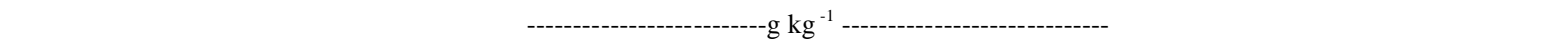 } \\
\hline Moisture & 143.4 & 450.1 & 258.7 & 3.8 \\
\hline Organic $\mathrm{C}$ & 196.3 & 369.6 & 301.3 & 1.8 \\
\hline Total $\mathrm{N}$ & 22.6 & 47.8 & 35.3 & 0.3 \\
\hline Total P & 11.1 & 38.1 & 19.2 & 0.3 \\
\hline Total K & 11.2 & 38.6 & 25.3 & 0.3 \\
\hline Total Ca & 17.9 & 68.4 & 29.3 & 0.5 \\
\hline Total Mg & 3.0 & 8.7 & 5.7 & 0.1 \\
\hline Lignin & 18.8 & 326.0 & 81.1 & 2.6 \\
\hline Cellulose & 90.4 & 393.9 & 191.7 & 3.4 \\
\hline Hemicellulose & 13.0 & 279.8 & 156.4 & 4.5 \\
\hline \multicolumn{5}{|c|}{ 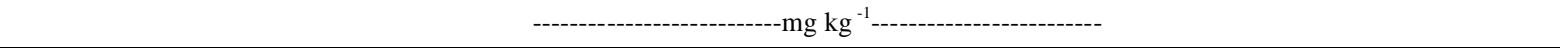 } \\
\hline $\mathrm{Fe}$ & 800 & 13200 & 245 & 117 \\
\hline $\mathrm{Cu}$ & 100 & 1000 & 439 & 11 \\
\hline $\mathrm{Mn}$ & 200 & 1100 & 541 & 13 \\
\hline $\mathrm{Zn}$ & 200 & 1300 & 486 & 12 \\
\hline $\mathrm{Al}$ & 300 & 15400 & 2437 & 154 \\
\hline $\mathrm{NO}_{3}-\mathrm{N}$ & 23 & 12346 & 1656 & 137 \\
\hline $\mathrm{NH}_{4}-\mathrm{N}$ & 3250 & 20066 & 8944 & 208 \\
\hline
\end{tabular}

${ }^{\mathrm{a}}$ Minimum, maximum, mean, and standard error of the mean for 87 samples analyzed in triplicate.

Table 3. CORRELATION of Selected Poultry Waste Characteristics with $\mathbf{N}$ Mineralization results ${ }^{\mathrm{a}}$

\begin{tabular}{|c|c|}
\hline Component & \multicolumn{1}{c|}{ r $^{-1}$} \\
\hline \hline Organic C & $0.16^{* *}$ \\
\hline Total N & $0.02^{\text {ns }}$ \\
\hline $\mathrm{C}: \mathrm{N}$ & $0.06^{\mathrm{ns}}$ \\
\hline $\mathrm{NO}_{3}-\mathrm{N}$ & $0.23^{* *}$ \\
\hline $\mathrm{NH}_{4}-\mathrm{N}$ & $0.25^{* *}$ \\
\hline Lignin & $-0.22^{* *}$ \\
\hline cellulose & $0.06^{\mathrm{ns}}$ \\
\hline hemicellulose & $0.24^{* *}$ \\
\hline
\end{tabular}

${ }^{\text {a C} C o r r e l a t i o n ~ r e s u l t s ~ f o r ~} 87$ waste samples and 234 soil-waste incubations, both analyzed in triplicate.

significant at $1 \%$ level.

${ }^{\mathrm{ns}}$ not significant.

jection to high temperature and pressure. The poor relationship between this method and $\mathrm{N}$ mineralized during incubation suggests that autoclaving poultry wastes with $0.01 \mathrm{M}$ $\mathrm{CaCl}_{2}$ at $121^{\circ} \mathrm{C}$ for 16 hours would not provide a good predictor of $\mathrm{N}$ availability. Moreover, the relationship is negative, indicating that $\mathrm{N}$ mineralization decreased with increasing amounts of $\mathrm{N}$ released in autoclave- $\mathrm{CaCl}_{2}$ extractions.

\section{Sodium Bicarbonate Extraction}

Sodium bicarbonate, a mild alkaline solution, has been used to extract nitrogenous compounds in the soil [9]. Thus, it was considered to have potential to predict available $\mathrm{N}$ in poultry wastes. This method provided the second best relationship with $\mathrm{N}$ mineralized (Table 4). Data (not shown) were not as scattered as in most of the other methods, but the 
Table 4. Relationships Between N Bioavailability Predictors and N Mineralized ${ }^{\mathrm{a}}$

\begin{tabular}{|c|c|c|c|c|c|c|}
\hline Method & Minimum & Maximum & Mean & Std. Error & $\mathbf{r}$ & $\mathbf{r}^{2}$ \\
\hline & \multicolumn{3}{|c|}{----- mineralized $\mathrm{N}$ mg/kg----- } & & & \\
\hline Bicarbonate & 4962 & 15639 & 9775 & 148 & 0.59 & 0.35 \\
\hline Permanganate & 1703 & 18706 & 8651 & 345 & 0.78 & 0.61 \\
\hline Pepsin & 4967 & 15371 & 9545 & 155 & -0.32 & 0.10 \\
\hline Protein & 346 & 1117 & 751 & 11 & 0.26 & 0.07 \\
\hline Soil incubation & -31 & 330 & 95 & 5 & & \\
\hline
\end{tabular}

${ }^{\mathrm{a}}$ Minimum, maximum, mean, and standard error of the mean for 234 soil-waste incubations conducted in triplicate.

relationship was not good enough for predicting $\mathrm{N}$ mineralized from poultry wastes.

\section{Walkley-Black (Acid dichromate) Digestion}

This method was originally used to determine soil organic matter using dichromate as an oxidizing agent. A previous study on organic residues (such as manures, sludges, and composts) [12], resulted in significant correlations between amount of $\mathrm{N}$ mineralized during incubation and $\mathrm{N}$ released into Walkley-Black acid dichromate digests. In this study, $\mathrm{N}$ released from poultry litter using Walkley-Black digestion also resulted in a significant (negative) correlation with $\mathrm{N}$ mineralized during 60-day incubations, but the correlation was very low (Table 4). These results suggest this

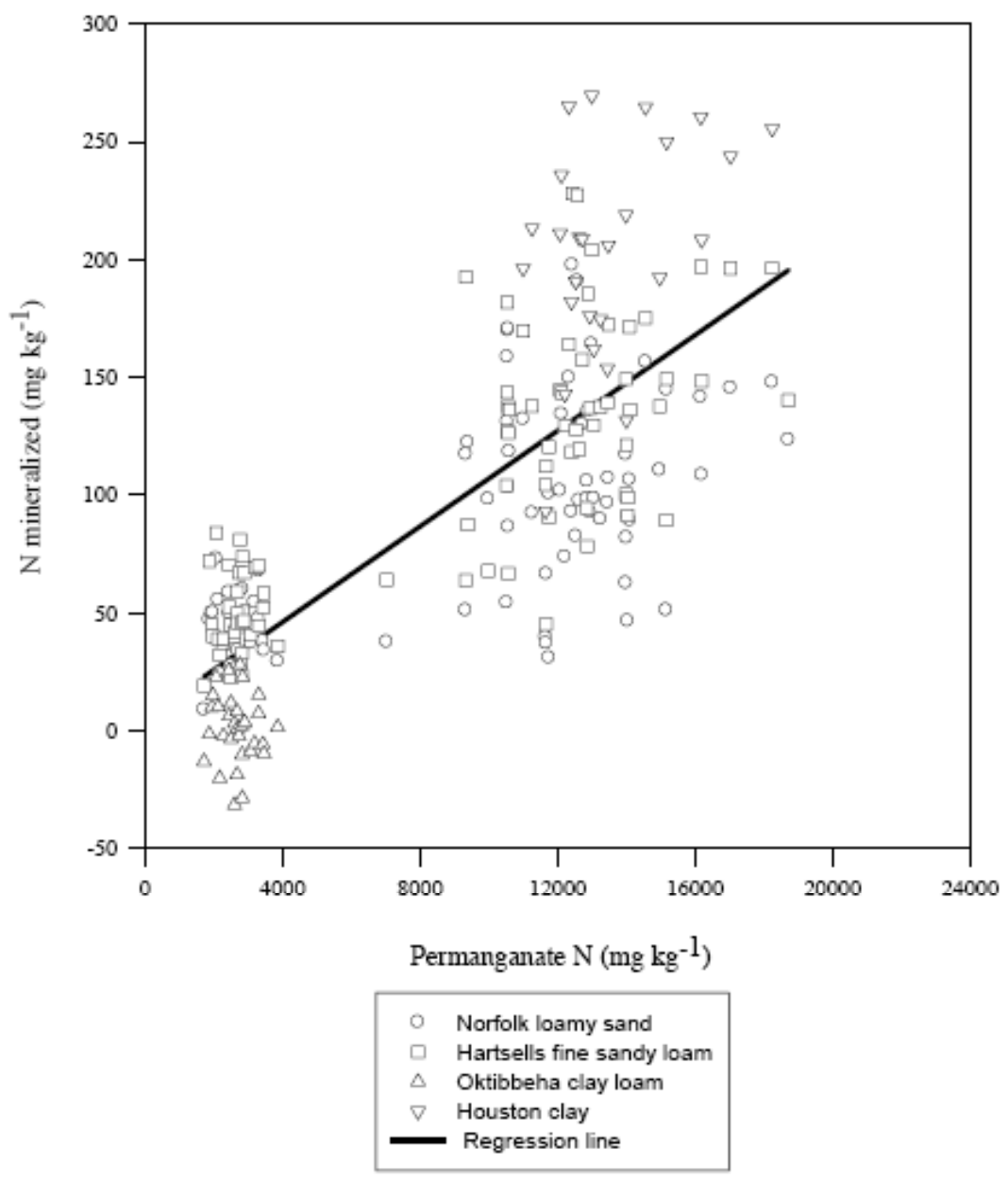

Fig. (1). Nitrogen released by permanganate digestion vs $\mathrm{N}$ mineralized in incubation. 
method is not a good choice for predicting $\mathrm{N}$ availability from poultry wastes.

\section{Acid Permanganate Digestion}

Another method that was attempted in an effort to measure potentially available $\mathrm{N}$ in poultry wastes was oxidative release of $\mathrm{NH}_{4}-\mathrm{N}$ by acid permanganate. This method gave the highest correlation coefficient of any method tried (Fig. 1; Table 4). The $\mathrm{r}^{2}$, however, indicates that variation in available $\mathrm{N}$ in poultry wastes by acid permanganate digestion accounted for only $61 \%$ of the variation in $\mathrm{N}$ mineralized. This relationship is not good enough to indicate that the method would be useful in a predictive sense. Also, two distinct data clusters at both ends of the regression line (Fig. 1) contribute to the relationship's weak appearance.

\section{Pepsin Digestion}

Pepsin is best known as an enzyme that is involved in gastric digestion, and the test is designed for determination of protein digestibility in animal feeds [14]. A study was conducted to test a number of chemical methods as predictors of available $\mathrm{N}$ in different manures showed that $\mathrm{N}$ released by pepsin digestion gave the highest correlation $\left(r^{2}=0.81\right)$ [27]. Results from this experiment, however, showed a very poor correlation (Table 4). Pepsin digestion would not be a good predictor of $\mathrm{N}$ mineralized from poultry wastes under the conditions of this study.

\section{Protein Extraction}

Most of the $\mathrm{N}$ present in poultry waste is organic in nature and a large part of it is derived from protein. It is therefore important to determine if poultry waste proteins are labile $\mathrm{N}$ sources and if protein extraction would be a good predictor of $\mathrm{N}$ availability. Results from this study show that extractable poultry waste proteins very poorly correlated with $\mathrm{N}$ mineralized (Table 4). Similar poor results were found for sewage sludge [16].

\section{CONCLUSIONS}

Results from this study cannot provide a firm recommendation as to the best chemical bioavailability predictor of $\mathrm{N}$ release following poultry waste application. However, there may be other chemical or biochemical tests of $\mathrm{N}$ availability in poultry wastes that were not tested in this study that could serve as good predictors.

\section{REFERENCES}

[1] Wood CW, Torbert HA, Delaney DP. Poultry litter as a fertilizer for bermudagrass: effects on yield and quality. J Sustain Agric 1993; 3: 21-36.

[2] Flynn RP, Wood CW, Touchton JT. Nitrogen recovery from broiler litter in a wheat-millet production system. Bioresour Technol 1993; 44: 165-73.

[3] Kingery WL, Wood CW, Delaney DP, Williams JC, Mullins GL. Impact of long-term land application of broiler litter on environmentally related soil properties. J Environ Qual 1994; 23: 139-47.
[4] US Environmental Protection Agency. Quality criteria for water. US Government Printing Office: Washington, DC 1976.

[5] Keeney DR, Nelson DW. In: Page AL, Miller RH, Keeney DR, Eds. Nitrogen - inorganic forms. Methods of soil analysis: Part 2. 2nd ed. Amer Soc Agron and Soil Sci Soc Amer, Madison, WI 1982; pp. 643-98.

[6] Hue NV, Evans CE. Procedures used for soil and plant analysis by the Auburn University Soil Testing Laboratory. Auburn University, AL: Alabama Agric Exp Sta 1986.

[7] Goering HK, Van Soest PJ. Forage fiber analysis: apparatus, reagents, procedures, and some applications, USDA Agric Handbook 379, US Gov Printing Office, Washington, DC, 1970.

[8] Smith SJ, Stanford G. Evaluation of a chemical index of soil nitrogen availability. Soil Sci 1971; 111:228-32.

[9] MacLean AA. Measurement of nitrogen supplying-power of soils by extraction with sodium bicarbonate. Nature 1964; 203: 1307-8.

[10] Walkley A. A critical examination of a rapid method for determining organic carbon in soils: effect of variations in digestion conditions and of inorganic soil constituents. Soil Sci 1947; 63: 251-63.

[11] Nelson DW, Sommers LE. In: Page AL, Miller RH, Keeney DR, Eds. Total carbon, organic carbon, and organic matter. Methods of soil analysis: Part 2. 2nd ed. ASA and SSSA, Madison, WI 1982; pp. 571-9.

[12] Douglas BF, Magdoff FR. An evaluation of nitrogen mineralization indices for organic residues. J Environ Qual 1991; 20: 368-72.

[13] Stanford G, Smith SJ. Oxidative release of potentially mineralizable soil nitrogen by acid permanganate extraction. Soil Sci 1978 ; 126: 210-18.

[14] Horwitz W, Ed. Official methods of analysis. 11th ed. Washington, DC Association of Official Analytical Chemists 1970; pp. 127-8.

[15] Lowry OH, Rosebrough NJ, Farr AL, Randall RJ. Protein measurement with the Folin phenol reagent. J Biol Chem 1951; 193: 265-75.

[16] Lerch RN, Barbarick KA, Sommers LE, Westfall DG. Sewage sludge proteins as labile carbon and nitrogen sources. Soil Sci Soc Am J 1992; 56: 1470-76.

[17] Jenkinson DS. Chemical tests for potentially available nitrogen in soil. J Sci Food Agric 1968; 19: 160-68.

[18] Sims, GK, Ellsworth TR, Mulvaney RL. Microscale determination of inorganic nitrogen in water and soil extracts. Comm Soil Sci Plant Anal 1995; 26: 303-16.

[19] SAS Institute Inc. SAS/STAT User's Guide, Release 6.04. Cary, NC 1993.

[20] Hileman LH. The fertilizer value of broiler litter. Arkansas Agric Exp Sta Rep Ser 158, Univ of Arkansas Fayeteville, AR 1967.

[21] Perkins HF, Parker MB. Chemical composition of broiler and hen manures. Ga Agric Exp Stat Bull 1971; 90: 5-17.

[22] Mitchell CC, Donald DO. The value and use of poultry manures as fertilizer. Alabama Coop Ext Serv Circ ANR-244. Auburn AL, 1995.

[23] Chescheir GM III, Westerman PW, Safley LM Jr. Laboratory methods for estimating available nitrogen in manures and sludges. Agric Wastes 1986; 18: 175-95.

[24] Reddy KR, Overcash MR, Khaleel R. Nitrogen, phosphorus, and carbon transformations in coastal plain soil treated with animal manures. Agric Wastes 1980; 2: 225-38.

[25] Gale PM, Gilmour JT. Carbon and nitrogen mineralization kinetics for poultry litter. J Environ Qual 1986; 15(4): 423-6.

[26] Stanford G, Demar WH. Extraction of soil organic nitrogen by autoclaving in water: the $\mathrm{NaOH}$-distillable fraction as an index of nitrogen availability in soils. Soil Sci 1969; 107: 203-6.

[27] Castellanos, JZ, Pratt PF. Mineralization of manure nitrogen correlation with laboratory indexes. Soil Sci Soc Am J 1981; 45: 354-7.

This is an open access article licensed under the terms of the Creative Commons Attribution Non-Commercial License (http://creativecommons.org/licenses/ by-nc/3.0/) which permits unrestricted, non-commercial use, distribution and reproduction in any medium, provided the work is properly cited. 